\title{
Development of an Oral Push-Pull Osmotic Pump of Fenofibrate-Loaded Mesoporous Silica Nanoparticles [Corrigendum]
}

Zhao Z, Wu C, Zhao Y, Hao Y, Liu Y, Zhao
W. Int J Nanomedicine. 2015;10:1691-1701.

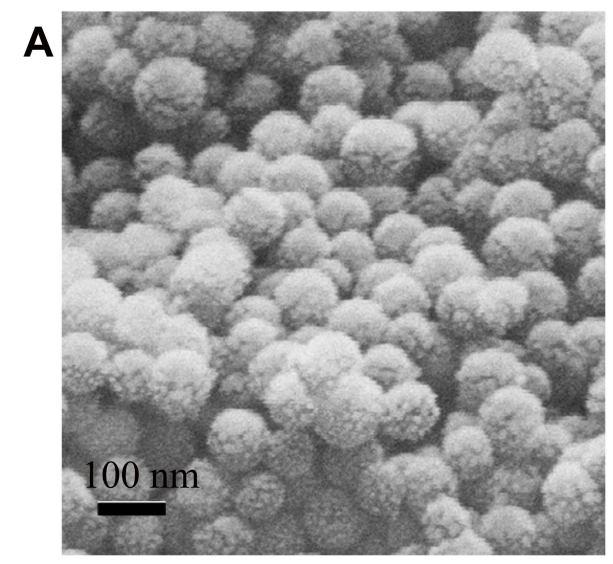

The authors have advised due to an error at the time of figure assembly, Figure 1B on page 1694 is incorrect. The correct Figure 1 is as follows.

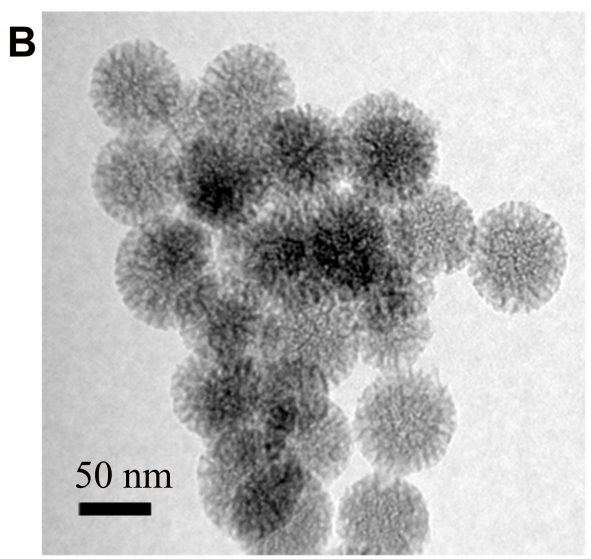

Figure I SEM (A) and TEM (B) images of MSNs.

Abbreviations: MSN, mesoporous silica nanoparticle; SEM, scanning electron microscopy; TEM, transmission electron microscopy.

The authors apologize for this error and advise it does not affect the results of the paper.

\section{Publish your work in this journal}

The International Journal of Nanomedicine is an international, peerreviewed journal focusing on the application of nanotechnology in diagnostics, therapeutics, and drug delivery systems throughout the biomedical field. This journal is indexed on PubMed Central, MedLine, CAS, SciSearch ${ }^{\circledR}$, Current Contents ${ }^{\mathbb{B}} /$ Clinical Medicine,
Journal Citation Reports/Science Edition, EMBase, Scopus and the Elsevier Bibliographic databases. The manuscript management system is completely online and includes a very quick and fair peer-review system, which is all easy to use. Visit http://www.dovepress.com/ testimonials.php to read real quotes from published authors. 